\title{
AC 2009-388: OF BYTES AND BOOKS: KEEPING IT ALL TOGETHER AND STILL CALLING IT A LIBRARY
}

\section{Adriana Popescu, Princeton University}

Adriana Popescu held positions in science and technology librarianship for more than ten years, both in Canada and United States. She holds a graduate degree in Civil Engineering from the Technical University of Civil Engineering in Bucharest and an MLS degree from Rutgers University. Before joining Princeton University Library in 2001 as Plasma Physics Librarian, she was the Head of the Research \& Information Center at the NRC Institute of Ocean Technology in St. John's, Newfoundland (Canada). Since 2006 she holds the position of Engineering Librarian at Princeton University.

\section{Patricia Gaspari-Bridges, Princeton University}

Patricia Gaspari-Bridges is Head of the Science and Technology Libraries and Assistant University Librarian for the Special Libraries Department at Princeton University. She has spent over twenty-five years in science and technology librarianship at Princeton, and continues to hold positions as Geosciences and Map Librarian and Head of the Peter B. Lewis Science Library. Before joining Princeton, she worked in various library positions, including at the University of Pennsylvania in Philadelphia. She earned a B.A. at the University of Pennsylvania and an MLS from Rutgers University. 


\title{
Of Bytes and Books: Keeping it All Together and Still Calling it a Library
}

\begin{abstract}
When the reference desk is becoming obsolete and the library's collection is stored in bytes, maintaining the identity of a library can be challenging. If the library space is not reclaimed by the academic department for lab space or offices, can the engineering library survive in its traditional configuration with no reference desk and volumes disappearing off its shelves? In 2001 Princeton University opened the Friend Center for Engineering Education, a brand new building housing the Engineering Library, several computer labs and state of the art classrooms, but less than 10 years later, the library is contemplating a physical renovation to address current trends in users' needs and to accommodate future collection requirements for new and emerging engineering research areas. Libraries have redefined their roles over many years of technological progress. In the case described, change proves once again that it can offer new prospects and fresh opportunities for asserting the role of the library in the academic environment.
\end{abstract}

\section{Introduction}

In its early days, the library at Princeton University consisted of a gift from Governor Belcher of 474 books, which in 1750 made the library the sixth largest in the colonies. Since then, the library has grown over the years to a system that today consists of one central library and 9 specialized libraries, holding over 6 million books. Historically, the Library has gained from the generous support of Princeton donors, and the last decade, in particular, has been a beneficial one, with a number of library building/renovation projects supported by alumni donations. Driven mostly by the departments' need to expand lab and office space into areas occupied by small departmental libraries, a concerted effort was made to consolidate smaller libraries in new buildings or renovate existing library spaces. Just a few impressive library building and renovation projects of the last decade include the Stokes Library for Public and International Affairs that was established in a newly dedicated building in 2000, the Engineering Library moved into a brand new building in 2001, the Marquand Library of Art and Archaeology renovation and expansion was completed in 2003, and five science branch libraries merged into the new Lewis Library, designed by renowned architect Frank Gehry, in 2008. But the last decade has also been marked by profound technological changes, changes in the library's collecting focus, as well as changes in users' information seeking behavior. These changes affected not only space planning, but also staffing requirements and service delivery methods, making it necessary to take a critical look at our existing libraries even when they are only eight years old. In the wake of planning and building Lewis Science Library, new user needs were revealed and valuable lessons were learned, which have been applied to the project at the Engineering Library, described in this paper.

\section{History of Engineering Library}

The Engineering Library supports the educational and research activities of the School of Engineering and Applied Science (SEAS) at Princeton University and it is one of the nine 
existing specialized libraries. The School has 130 faculty members and the student population consists of 825 engineering undergraduates (Spring 2008) and 516 graduate students (2008/09 enrollment). The engineering collection traces its beginnings as early as 1906, when along with the botany collection, was housed in the old Green School of Science ${ }^{1}$. In 1962 the School of Engineering built a new library space in the E-Quad, the building housing all the engineering departments, but by the mid-1990s, the need for laboratory space became very acute. When University Trustee Dennis Keller '63 made the generous gift to the School of Engineering for a new building, the library received a new home in the Friend Center for Engineering Education.

Designed by internationally acclaimed architect Henry Cobb of Pei, Cobb, Freed and Partners, Friend Center opened its doors in September 2001. The building houses high-tech classrooms and computer clusters, videoconferencing facilities, a spacious convocation hall, a 250-seat auditorium, along with the Engineering Library, for a total of 70,500 square feet. The library occupies $40 \%$ of the building and one of its novel features was the presence of eight small classrooms located within the library that are used for classes during the day and as communal study rooms in the evenings. When the library opened in its current location at Friend Center, it was considered the most technologically advanced library on campus and it offered patrons a dramatic improvement in space and services, due to the architectural design which brought in more comfortable space for student use ${ }^{2}$.

Since 2001, a significant number of changes in services and library collections (becoming increasingly electronic), and users' needs (collaborative work conducted in small groups), in addition to plans for growth and expansion of the School of Engineering and Applied Sciences (student enrollment), made it necessary to re-evaluate the use of the space in the Engineering Library.

\section{Current Physical Layout}

The Engineering Library spans three levels for a total of 28,200 square feet and is equipped for wireless network access. The $1^{\text {st }}$ floor is the entrance to the library and is the area with the most transient traffic, where all of the reference and circulation transactions take place, and where the staff main office is located. Because of all the interactions on the first floor, this space is not viewed as a quiet study space, but rather a group study space. The five large tables are always occupied, mostly by pairs of students studying together. At times students will wander around in the hope that one of these tables will be vacated so that another group can use it. The tables on the $2^{\text {nd }}$ and $3^{\text {rd }}$ floor are used entirely for individual study; therefore, aside from classrooms and seminar rooms, the $1^{\text {st }}$ floor is the only space where students can gather in groups and work together without worrying about disturbing others.

It has been observed that when classes are in session, all computers on the $1^{\text {st }}$ floor are quickly occupied by students checking their email or printing papers, particularly in the periods between classes.

The $1^{\text {st }}$ floor encompasses the reference collection and part of the bound periodicals collection. The reference desk is centrally located and the circulation desk is about 20 feet away from it. 
Staff offices, the staff room and an electronic classroom are also located on this level. The user space consists of 5 tables with 20 seats, 14 public PCs, and 2 printing stations.

The $2^{\text {nd }}$ floor houses the unbound journals along with the remaining bound periodical collection. A comfortable soft seating area is located adjacent to the unbound journal collection. An information desk staffed by a regular library employee Monday through Friday from 9am to 5pm and staff offices for document delivery processing and print collection maintenance are also located on this level. The user space consists of 16 tables of various sizes with 80 seats, 11 lounge chairs, 4 classrooms, 8 public PCs and 2 printing stations.

The $3^{\text {rd }}$ level of the library houses the monographs and dissertations in a combination of compact and stand alone shelving. The user space on this level consists of a combination of 11 tables of various sizes with 24 seats, 4 lounge chairs, and 4 public PCs with a printing station. Also located here are 2 study rooms, 4 classrooms, and a multimedia project room equipped with 2 PCs, 2 public scanners and a printer.

\section{Evolving Collections}

About $30 \%$ of the space on the main floor is currently allocated to the bound journals collection. Since 2001, the library has acquired significant electronic collections of journal backfiles and archives, therefore the majority of engineering journals are available online. Unlike books, users prefer to use journals online and the online access statistics monitored by the library reflect this trend. In fact, all new journal subscriptions acquired since 2006 have been electronic format only. Having the print copy of a journal on site is no longer a requirement, therefore during the 2005/06 and 2006/07 academic years, 4,652 bound journal volumes were sent to remote storage and 2,084 volumes of duplicate volumes were withdrawn since these titles were available electronically. It is expected that by July 1 2009, 2,000 more volumes will be sent to remote storage or withdrawn.

Table 1. The Engineering Library Collection in Numbers

\begin{tabular}{|l|r|r|}
\hline Library Collection & $\mathbf{2 0 0 1}$ & $\mathbf{2 0 0 9}$ \\
\hline Monographs (vols.) & 74,700 & 71,000 \\
\hline Bound periodicals (vols.) & 31,700 & 22,000 \\
\hline Unbound serial subscriptions & 1,400 & 550 \\
\hline Theses \& dissertations (vols.) & 3,145 & 3,780 \\
\hline
\end{tabular}

The Engineering Library held a significant collection of print technical reports before its relocation to Friend Center, but when the University Library built a high density storage facility off-site, most of the collection was transferred there and no new print reports are being added. The monograph collection has gone through regular review cycles of weeding duplicates and relocating older and marginal interest items to the off-site facility. In fact, between 2001 and 2007, more books have been withdrawn or transferred than have been added to the collection (table 1).

After seven years of very low levels of monographic acquisitions (approx. 6000 new volumes added to the collection from 2001 to 2007), in 2008 the library established a comprehensive book 
approval plan, which is bringing in roughly 2,000 new volumes per year. This change and shift to collecting focus and priorities came after consultations with the six academic departments of the School of Engineering and as a response to the School's adopted strategic plan, which places the focus of research and priorities for the academic programs on four major areas of societal need: energy, environment, health and security. The school embarked on a targeted growth process in these four areas, by creating new faculty positions and supporting those new positions with a commensurate growth in student body and new research facilities. The increased focus on energy and environment research has also brought into play a closer partnership with the University's Bendheim Center for Finance, because of the inherent challenges in financial engineering posed by carbon trading or the effects of bio-fuel production on commodity prices. These new and emerging research areas required enhanced collections, and in 2007, during informal discussions with departmental chairs and with faculty members, it was acknowledged that the library's journal collection (print and electronic) was comprehensive in coverage and high in quality, but the monographic collection was considered to be out of date and below standard for supporting the new and growing areas of research. Faculty members have also expressed a preference for print format for books, rather than electronic, with the exception of reference works and textbooks, which they prefer in electronic format.

All the factors mentioned above, have been taken into consideration when the book approval plan was established and launched in 2008. At the time when the bound journal shelves were rapidly emptying, some of the space created was quickly filling with monographs. With the significant drop in collection volume (table 1), it has been established that the remaining bound journal collection can be consolidated on the $2^{\text {nd }}$ floor. After assessing the growth rate for the monograph collection, theses and dissertations, and the attrition rate for the bound journal collection, $37 \%$ of the current shelving space on the first floor has been identified as sufficient to house the relatively small print reference collection and the new books display.

\section{Value-added Services}

At the time the library was planned, the reference desk was the mainstay of the academic library, its heart and soul, and the size and location of the reference desk on the first floor of the Engineering Library, is clearly making that statement (fig. 1). When the library opened in 2001, the reference desk was staffed Monday through Friday, 9am to 6pm. The volume of transactions taking place at the desk has always been modest, while the circulation desk located right at the entrance of the library has been the preferred point of service for users with inquiries of all types. Most inquiries received at the reference desk tended to be directional or basic in nature. The coverage hours for the reference desk progressively decreased to the point that since 2005 there has been no staffing provided for the reference desk. Internet communication has become the preferred method of submitting reference inquiries and the relatively few reference inquiries received at the circulation desk are immediately referred to the professional librarian on site. The reference desk is currently used as work area for students hired to assist with specific collection processing projects. 


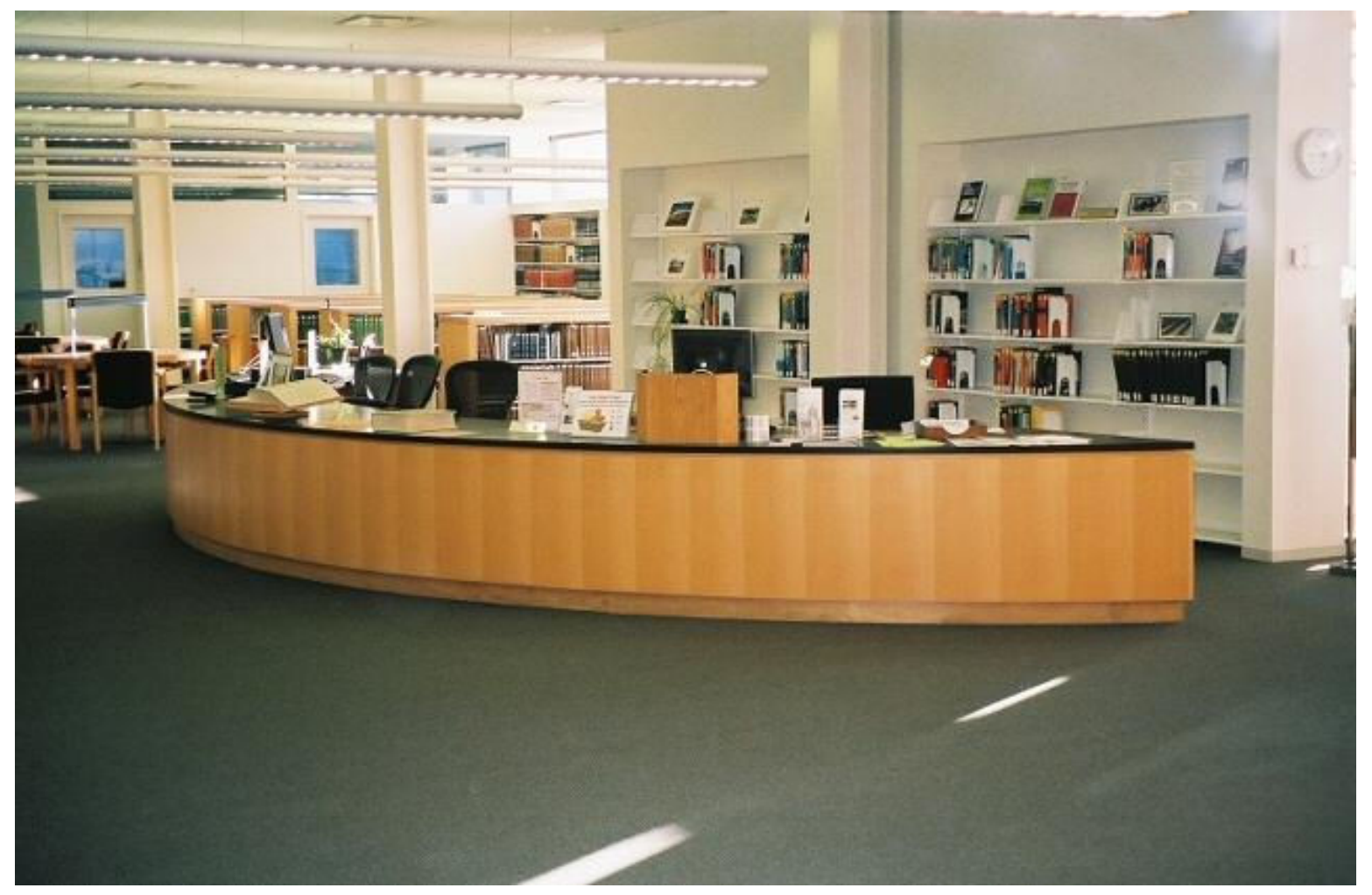

Figure 1. Reference Desk (Photo: B. Chamberlin, Princeton University Library)

With the circulation desk becoming the central information point for the users, it became clear that the library needed to closely monitor and examine the nature of the inquiries received there in order to ensure that users receive timely and quality service. The circulation desk is staffed by student assistants at all times, but the proximity of the circulation desk to the main staff office allows for closely overseeing the interactions of the student assistants with the users and guiding and coaching them in answering the questions. Training the circulation assistants to properly refer users when needed and assist users beyond performing basic circulation transactions has become a key component of the student hiring and training process. Even though the large reference desk is still present in the library, the circulation desk has become the bona fide information service point of the library, and is now referred to as the Information Desk (fig. 2). 


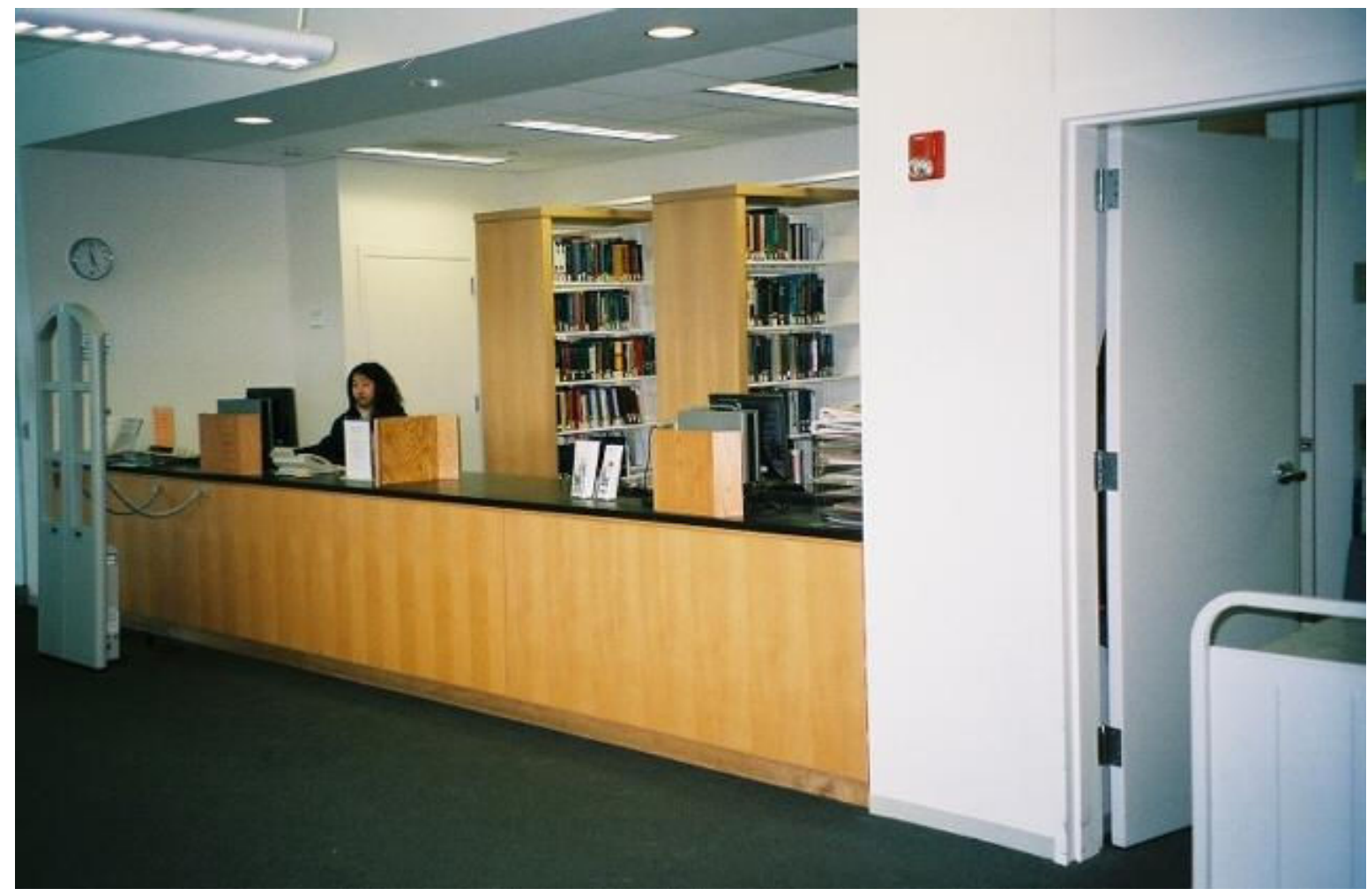

Figure 2. Information Desk / formerly Circulation Desk (Photo: B. Chamberlin, Princeton University Library)

While enhanced staff training was essential to assure quality services, it was equally important that the library find a solution to consolidate, streamline and analyze the reference transactions (of any type and form) conducted in person, at a service desk, via e-mail or chat. After reviewing the in-house solutions available and researching the commercial solutions in the academic library market, at the beginning of the academic year 2008-2009, the Engineering Library (along with Lewis Science Library) implemented two systems offered by Altarama Information Systems: RefTracker, and DeskStats. RefTracker, a web-based reference and requests tracking and analyzing system, has provided the necessary framework for handling reference questions and inquiries submitted online (via web or e-mail, or chat). DeskStats, an online system for recording short reference questions, has been configured to record all types of inquiries received at the Information Desk, from questions related to policies and procedures to questions related to the use of computers and electronic equipment in the library.

The transactions recorded at the Information Desk (by the student assistant on duty) using DeskStats, for the academic year 2008/09 (from September 1, 2008 to date) show that users' most frequent questions are directional in nature and about locating materials in the Engineering Library. Only $7.98 \%$ of the questions received resulted in referrals to librarians (table 2), which confirmed the long-held observations of the library staff that users seek less and less in person reference assistance at the desk and validated the library's decision to discontinue the staffing of the reference desk. 
Table 2. Transactions Recorded at the Engineering Information Desk (Sept. 2008 to Feb. 2009)

\begin{tabular}{|c|c|c|c|c|c|c|c|}
\hline Transactions recorded & $<1$ Min & $1-5 \mathrm{~min}$ & $\begin{array}{l}5-10 \\
\min \end{array}$ & $\begin{array}{l}10-20 \\
\min \end{array}$ & $\begin{array}{l}>20 \\
\min \end{array}$ & Total & Total \% \\
\hline All other directional & 394 & 63 & 3 & 0 & 0 & 460 & $30.61 \%$ \\
\hline Building problems & 21 & 6 & 1 & 0 & 0 & 28 & $1.86 \%$ \\
\hline Building/Library access & 48 & 10 & 2 & 0 & 1 & 61 & $4.06 \%$ \\
\hline Circulation / Loan period & 70 & 25 & 5 & 0 & 1 & 101 & $6.72 \%$ \\
\hline Computers \& network & 38 & 13 & 2 & 1 & 0 & 54 & $3.59 \%$ \\
\hline Course reserves & 30 & 19 & 0 & 0 & 0 & 49 & $3.26 \%$ \\
\hline $\begin{array}{l}\text { Do you have this item? } \\
\text { Ejournals/database }\end{array}$ & 218 & 53 & 4 & 0 & 1 & 276 & $18.36 \%$ \\
\hline access & 1 & 4 & 0 & 0 & 0 & 5 & $0.33 \%$ \\
\hline Food & 7 & 0 & 0 & 0 & 0 & 7 & $0.47 \%$ \\
\hline Hours & 29 & 4 & 0 & 0 & 0 & 33 & $2.20 \%$ \\
\hline Instruction & 0 & 0 & 0 & 0 & 4 & 4 & $0.27 \%$ \\
\hline IT Support & 11 & 1 & 0 & 0 & 0 & 12 & $0.80 \%$ \\
\hline Lost \& Found & 40 & 6 & 0 & 1 & 0 & 47 & $3.13 \%$ \\
\hline Photocopiers & 18 & 4 & 0 & 0 & 0 & 22 & $1.46 \%$ \\
\hline Printers & 49 & 11 & 0 & 0 & 0 & 60 & $3.99 \%$ \\
\hline Reference & 49 & 19 & 0 & 0 & 0 & 68 & $4.52 \%$ \\
\hline Referrals & 83 & 35 & 2 & 0 & 0 & 120 & $7.98 \%$ \\
\hline Rooms, carrels, lockers & 7 & 7 & 0 & 0 & 0 & 14 & $0.93 \%$ \\
\hline Scanners & 10 & 1 & 0 & 0 & 0 & 11 & $0.73 \%$ \\
\hline Tours & 1 & 0 & 0 & 0 & 0 & 1 & $0.07 \%$ \\
\hline Where is it shelved? & 54 & 12 & 4 & 0 & 0 & 70 & $4.66 \%$ \\
\hline Totals & 1178 & 293 & 23 & 2 & 7 & 1503 & \\
\hline Totals (\%) & $78.38 \%$ & $19.49 \%$ & $1.53 \%$ & $0.13 \%$ & $0.47 \%$ & & $100.00 \%$ \\
\hline
\end{tabular}

A significant change in the use of the library was brought by the launch of the electronic document delivery service in 2002. The Engineering Library processes requests and delivers in electronic format papers, book chapters, newspaper articles and any other materials requested by faculty, professional and research staff, graduate students and senior undergraduates affiliated with the School of Engineering. Materials requested may be available in the vast electronic library collection, or they may be physically located at the Engineering Library, at the Lewis Science Library, at campus remote storage locations or they may not be available from Princeton's collections at all, in which case they are acquired through commercial document delivery providers or from our partners in the RapidILL resource sharing system. Regardless of the format and location of the items requested, the service aims to deliver within a 48 hour period from the time the request was submitted. At the time the document delivery service was launched in 2002, it was offered only to faculty; however, due to its extremely high popularity, it has expanded to a broader user population. The high visibility of the service and its increased popularity had some obvious consequences, such as decreased numbers of users' visits to the library with the purpose of finding and retrieving materials. While the library is located within 100 feet of the E-Quad building, faculty and graduate students are visiting the library less since we started offering the document delivery service. Another consequence of the service was the need to cross train all library staff to be able to perform the processes and operations related to the service, so regardless of the staffing situation at a certain time, the service can continue uninterrupted. 
Closely related to the electronic document delivery service and introduced around the same time is the electronic course reserve (E-reserve) service. The library provides access to course materials for close to 300 engineering courses, both graduate and undergraduate level. In addition to acquiring and processing print materials requested by the engineering teaching faculty for course reserve, the library scans and delivers to the library's e-reserve server book chapters, articles, class notes and other materials. Students enrolled in a specific class can access the readings in electronic format through Blackboard, the university course management system.

The reference, document delivery and reserve services are the pillars of an academic library's operation and they all draw on the rich collections of the library, both print and electronic. However, the ease and convenience of electronic delivery for all these services have contributed to a great extent to the detachment of the user from the physical library. With less of a need to come to the library to access information, the library has predominantly become the preferred and frequently the only study space on campus. How each library re-defines and configures its role as a social and research space is a process specific and unique to each institution, its culture and tradition. At Princeton University Library, this process started with direct conversations with the library users, occurring shortly after the Engineering Library opened in 2001, at the time when the university commenced the planning for a combined science library to be designed by Frank Gehry.

Planning for the Lewis Science Library began in 2001, the project broke ground in 2004 and the new library opened its doors in September 2008. The focus groups conducted with graduate and undergraduate students during the planning and building of the Lewis Science Library (2002, 2003 and 2008) revealed valuable insights about how Princeton students view the library and what their expectations are for the role of the library in their academic experience. When asked to envision the new science library, they frequently drew on their current experiences at the Engineering Library and other libraries on campus, therefore highlighting both positive and negative aspects of the existing libraries. The students' views expressed during the focus groups held have been crucial in determining the scope of the re-organization project at the Engineering Library. The next section summarizes the conclusions of the student focus group discussions that have been most influential in defining the Engineering Library project.

\section{Lessons Learned From Building Lewis Library: What Users Want}

The focus groups held in October 2002 and January 2003 were attended by science and engineering graduate students who were invited to bring to the table their wish list for the ideal library. They had an open agenda; all questions and ideas were encouraged. Broad areas of discussion included collections, user space, environment and design, and equipment and facilities. The Provost and University Librarian provided an overview of the building design and vision for "a new kind of library" -- a facility to reflect and facilitate interdisciplinary science teaching and learning at Princeton.

Students were in unanimous agreement that journal articles were the primary resource, but the future of journals was electronic and having a reliable archiving system was vital. However, they were also unanimous in their desire to have all print journal holdings on one floor. They wanted 
a section of popular magazines and newspapers in a comfortable reading area to see what's new in scientific and technical fields, and wanted more copies of popular titles and texts. Despite feeling that the future was electronic, they wanted sufficient shelf space to bring back some of the archived collections from offsite storage, making them more immediately accessible for research. There were considerable questions about where the collections would be shelved and how they would be arranged. Browsability was important to them. If collections could not be returned to campus, they wanted an efficient and easy way to retrieve them. Students asked that current and new collections remain on campus and that computers and tables be inter-mixed with the print collections.

All expressed the need for a variety of inspiring spaces to study and collaborate. In their view, a library should be a place for exchange of ideas and the space should encourage this exchange. The space should have good natural light and be comfortable. It should have a designated "quiet zone" and a "reading room". Group study rooms should be numerous with seating for 4-6 and have chalkboards and computer projection equipment. Students like large tables for spreading out books, journals and laptops. Comments on some existing libraries included that the Chemistry Library is "dignified and has a scholarly feel," the Engineering Library is "poorly designed and not very pretty," and Fine Library (Mathematics \& Physics) is "dignified, but somewhat dark and depressing." The students were concerned that the library design and construction should be as "green" as possible and asked the University to make this a priority in its planning.

With regards to equipment, students asked that more public and specialized computers and software should be available. The sciences are Mac-centric and a mix of Mac and PC computers was requested along with software appropriate for the sciences. Each user space should have power and data connections. The library should circulate laptops.

In February 2008, the Library held another focus group for science graduate students. While the students participating in the discussions this time were not the same as in 2002, many of the suggestions made six years earlier were heard again. However, there were some notable differences. This time, the students put a greater emphasis on preferred computer equipment and software. Again, more public Macs were requested, as well as more public scanners. A list of specialized scientific software packages was submitted, that included Matlab, Mathematica and ArcGIS, amongst other applications. Larger monitors, virtual access to their office computers, easier ways to save and transport large files, computer projectors, large display monitors in group study rooms, access to network printers from their laptops, and color printers were the mostrequested technology-related items.

With regards to collections, the students unanimously requested online textbooks citing the high cost of required texts for courses. When prompted about choosing between more computers or more books, in the end they preferred more books, both print and electronic, rather than more computers. They wanted a comfortable reading area to review new books, and tables located among the print collections rather than all in one place and isolated from the collections.

The same themes about comfortable and varied study spaces were heard in 2008, as they were in 2002. The students unanimously agreed that the most important requirement was that the library 
be a welcoming and comfortable place to study and work. They wanted "cozy" individual study areas, to be able to curl up with a laptop or a book in "comfy" soft seating. They wanted designated "quiet zones." There should be assigned and unassigned carrels and assigned study spaces for those writing dissertations. Study spaces should be well-lit, with task lamps on tables. The tables should be large for space to spread out. Group study rooms should be available with chalkboards instead of whiteboards. The library should have even temperature and humidity control. Snacks and beverages should be permitted in designated library spaces. And finally, the library should have liberal hours with some 24-hour spaces if possible.

In April 2008, the Library held a focus group for undergraduate majors from the science departments. Comments received were remarkably similar to those expressed by the graduate students a few months earlier. Similar requests for specialized science software packages, public scanners and color printers/copiers and preferences for study tables and reading spaces proximate to the print collections, along with extended library hours, were heard from the undergraduates.

An important issue discussed with all focus groups was whether the library should have only one service point for users where questions should be directed. Each of the groups stated that they found it confusing to have specialized desks for circulation, interlibrary loan, and reference. Students were never certain where to direct their questions, and preferred not to waste time making the wrong choice and then redirected to repeat their question at another desk. Many international students who are not familiar with the North-American library system still find it difficult to navigate between the various service points and may still be confused about the role of the reference desk ${ }^{3}$.

\section{The Engineering Library Project}

Getting to the point of formulating a proposal for the physical re-organization of the library has been a long process, one that started almost immediately after the library opened at Friend Center in 2001. In the case presented, it took years of monitoring the use of the space and the use of collections, assessing the impact that new services and service models had on user behavior, and constant communication with all user groups about their needs and satisfaction with the library and its collections. These observations, combined with the reality of a growing number of empty shelves and considerable space being taken by a retired reference desk, lead to the realization that adjustments to the physical layout of the library were necessary. In 2008, after consultations with the School of Engineering Dean's Office, a proposal has be submitted to the Library administration, then to the University administration, for a project to redesign and reconfigure the $1^{\text {st }}$ floor of the Engineering Library.

In general, to be successful in making the case for change in services and/or for physical redesign of the library, a number of factors should be monitored over a significant period of time (more than two years) and their impact assessed. In the case of the Engineering Library at Princeton University, the following factors created the drive for the project and at the same time supported the case for it:

- the changing nature of collections and the predominance of electronic format for scientific literature 
- effect of new communication technologies on user information seeking behavior

- introducing new e-services such as electronic document delivery, e-reserves and ereference

- changes in research focus and emerging research areas that require enhanced collections of all types and formats

- student needs related to libraries becoming the preferred and sometimes the only study and research space available on campus

- student needs for specific computing equipment and software applications

The goal of the project is to re-purpose the use of the space previously occupied by print collections (fig. 3) for user space (fig. 4), by infusing elements of an information commons ${ }^{4}$ into a traditional library space. The information commons area will provide the specific computing equipment and software applications that were identified by students as desirable, but at the same time, it will be integrated with the remaining elements of the traditional library space, such as the information desk, the reference collection, course reserve materials and new and popular books display. A general overhaul of the collection layout is planned in conjunction with this project, in an attempt to better group the remaining collections by format, in clearly defined and easily identified spaces.

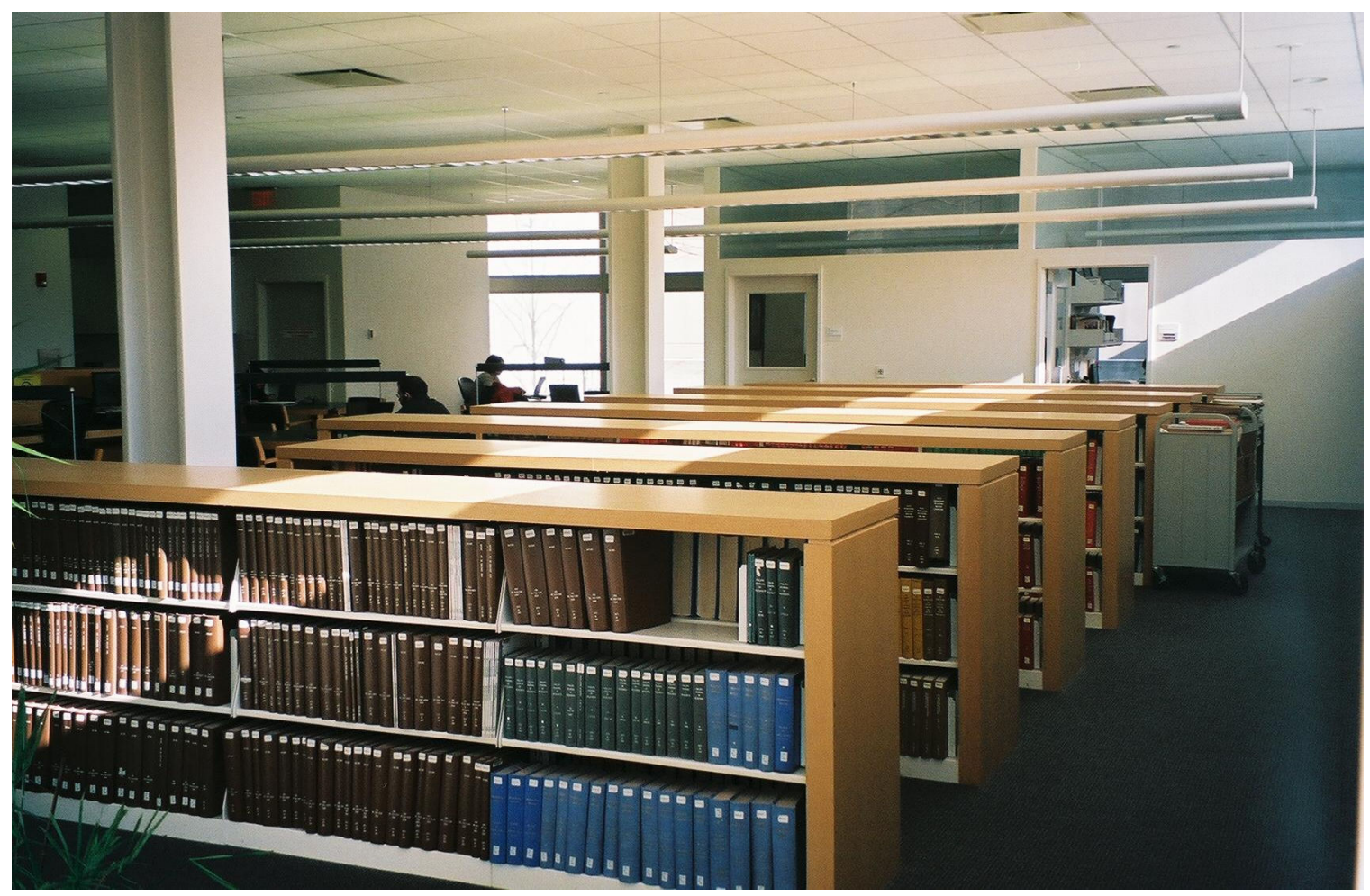

Figure 3. Surplus shelving (Photo: B. Chamberlin, Princeton University Library) 


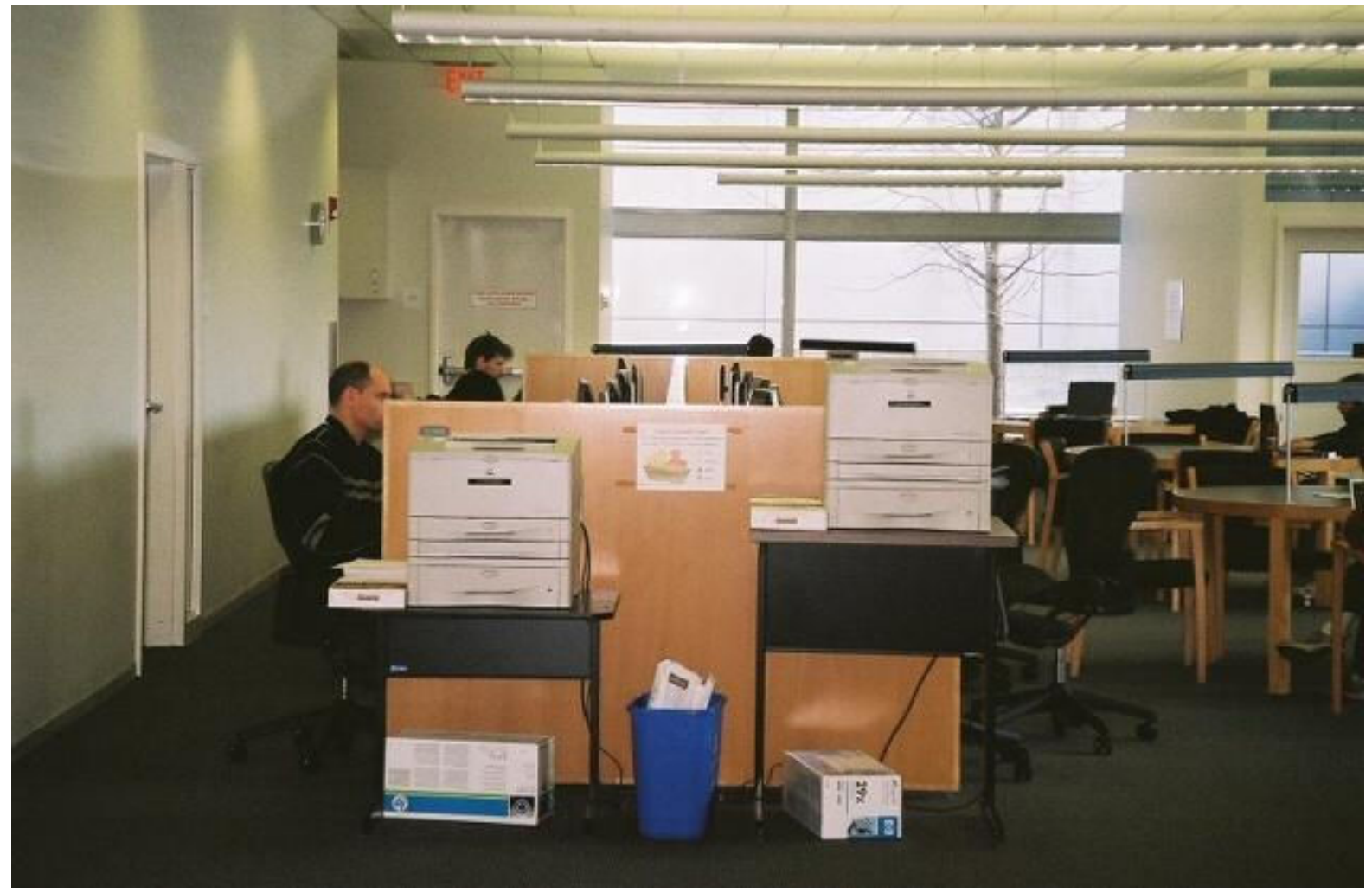

Figure 4. Area of multi-purpose use (Photo: B. Chamberlin, Princeton University Library)

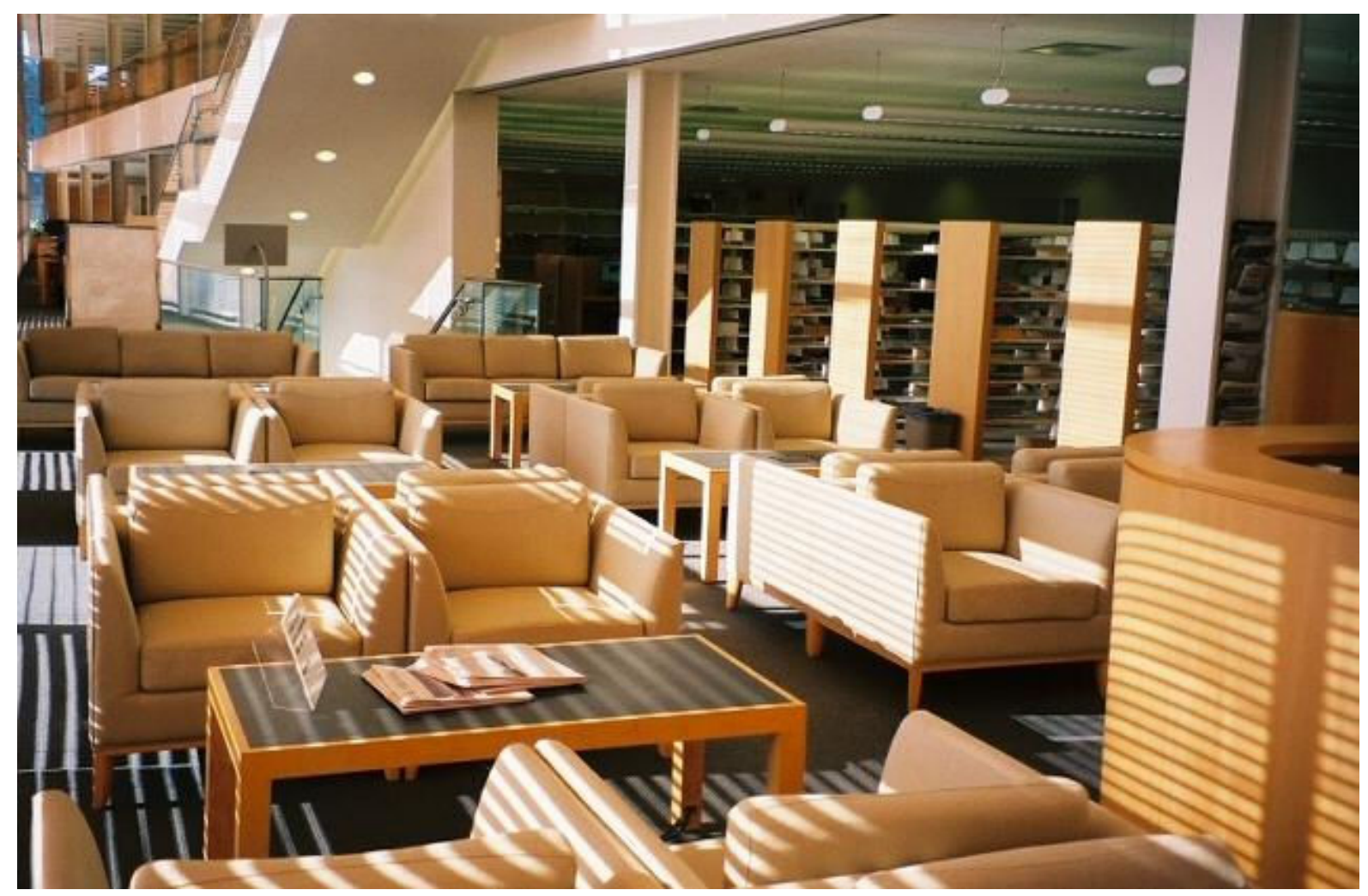

Figure 5. Preferred style of reading area (Photo: B. Chamberlin, Princeton University Library) 
At the time of this writing, the proposal for the redesign and reconfiguration work of the $1^{\text {st }}$ floor has been approved, and the work scheduled to be performed in several phases, began in February 2009. The stages of the project, listed in order of priorities for the library operations and in accordance with the university budgeting priorities, are as follows:

1. Add new software and specialized applications (ArcGIS, Matlab, Mathematica) to all existing library computers (completed).

2. Convert the circulation desk to support operations of an expanded Information Desk.

3. Remove the large reference desk and re-organize the space it occupies into a New Books and Books by Princeton Authors display and reading area with soft seating (similar to fig. 5).

4. Remove the free-standing low stacks and use the space to add 4 large tables with 16 seats.

5. Remove 3 tall shelving units near the library entrance and add 4 more stand-up computers in the space vacated.

6. Relocate the print reference collection to blend in with the user study areas.

7. Reorganize the collection layout to enhance access to the monograph collection and integrate user space with the print collection.

8. Improve signage and the visual navigation aids for better access to remaining print collection.

The project does not involve any major structural reconfiguration or architectural redesign of the library facilities. In fact, it is quite modest in scope compared to previous library renovation projects undertaken by the university, which in a way, makes this project unique. The budget is relatively small (as of Feburary 2009, estimated at \$50,000) and there will be limited invasive work and disruption to library operations. Upon the project's completion, the first floor of the library will be transformed into an information commons area, where users will be able to integrate and use technology and library resources (print and digital) in the learning process. This is not a new concept, it has been long adopted by many academic libraries, but in the case of the Engineering Library at Princeton University, the commons area is created in an existing, traditional library setting and will blend a modern, interactive commons space with existing teaching spaces and traditional library spaces (as found on the upper two levels).

The changes in collections and service delivery methods described in this paper may not have been markedly visible to the Engineering Library users, who consistently benefited from quality services and access to collections, even without a reference librarian sitting at the reference desk. While it may be difficult to predict what the library of the future will look like or be like, the end product of this project will be a library that will aim to satisfy a wide range of users' needs; an inspiring place conducive to learning and collaborative work, where technology and library resources are integrated and readily available; a library without a reference desk and very few print journals, but bursting with books; a library where the staff performing the various services may be inconspicuous to the user, but who are nonetheless available in person or online for 17.5 hours/day. High speed communications and web technologies have re-purposed the function of the library and its services, but the library establishment will continue to thrive, both as an institution and a physical presence at Princeton University ${ }^{5}$. 
1. G. Lange, "Princeton's science libraries and labs - a genealogy,” PRINCETON Alumni Weekly, vol. 109, no. 2, 2008, retrieved on 02/05/09 at http://paw.princeton.edu/issues/2008/10/08/pages/1822/.

2. S. Peters, "Friend Center is dedicated; Building is a testament to an eternal friendship," E-Quad News, vol. 1, no. 1, 2001.

3. Y. Liao, et al., "Information-Seeking Behavior of International Graduate Students vs. American Graduate Students: A User Study at Virginia Tech 2005," College \& Research Libraries, vol. 68, no. 1, 2007, pp. 525.

4. Leslie Haas and Jan Robertson, "The Information Commons," ARL SPEC Kit 281, 2004, retrieved on 02/05/2009 at http://www.arl.org/bm doc/spec281web.pdf .

5. M. Noden, "A New Chapter for Libraries: Humanists ponder what will become of libraries in the digital age," Princeton Alumni Weekly, vol. 109, no. 7, 2009, pp. 42-47. 